\title{
The concept of development of the labor protection management system in small business in Uzbekistan
}

\author{
Mamura ATABAEVA ${ }^{1}$, Larisa PETROSOVA ${ }^{2}$, Kakhramon ATABAEV ${ }^{3}$ \\ Tashkent State Technical University named after I. Karimov
}

\begin{tabular}{l} 
ARTICLE INFO \\
\hline Article history: \\
Received August 2021 \\
Received in revised form \\
20 August 2021 \\
Accepted 25 September 2021 \\
Available online \\
25 October 2021 \\
\hline Keywords: \\
small business, \\
SUOT, \\
labor protection, \\
accident, \\
management circle, \\
audit, \\
GOST, \\
outsourcing.
\end{tabular}

\begin{abstract}
This article discusses the issues of safety and labor protection in the field of small business. With the help of statistical, theoretical and practical analysis, the essence of the OSH management system at enterprises is revealed, and in particular the ambiguity of its application for small businesses. The article presents a comparative analysis of the $\mathrm{OSH}$ management system in its standard understanding and the possibility of integrating outsourcing into it. Based on the research carried out, a concept is proposed on the need to adjust the OSH management system. On the basis of corrective action, the integration of external management of labor protection for small businesses.
\end{abstract}

\section{Kichik biznerlarning mehnatni muhofazasini boshqaruv tizimini rivojlanish konsepsiyasi}

\section{Kalitso'zlar:}

kichik biznes,

$\mathrm{OSH}$,

mehnatni muhofaza qilish, baxtsiz hodisalar, boshqaruv doirasi, auditorlik, GOST, autsorsing.
ANNOTATSIYA

Ushbu maqolada kichik biznesda xavfsizlik va mehnatni muhofaza qilish bilan bog'liq masalalar muhokama qilinadi. Statistik, nazariy va amaliy tahlillar yordamida korxonalarda mehnatni muhofaza qilish tizimini boshqarish tizimining mohiyati ochib beriladi, xususan, uning kichik biznes uchun qo'llanilishining noaniqligi aniqlanadi. Maqolada mehnatni muhofaza qilish tizimini boshqarish tizimining standart tushunchasi va unga autsorsingni integratsiya qilish imkoniyat-larining qiyosiy tahlili keltirilgan. O'tkazilgan tadqiqotlar asosida mehnatni muhofaza qilish tizimini boshqarish tizimini moslash-tirish zarurati to'g'risida kontseptsiya taklif etiladi. Tuzatish choralari asosida kichik biznes sub'ektlari uchun mehnatni muhofaza qilish bo'yicha tashqi bo'limlarni birlashtirish taklif etiladi.

\footnotetext{
${ }^{1}$ Senior lecturer, Tashkent State Technical University named after I. Karimov, Tashkent, Uzbekistan.

2 Docent, Tashkent State Technical University named after I. Karimov, Tashkent, Uzbekistan.

${ }^{3}$ Doctoral student, Tashkent State Technical University named after I. Karimov, Tashkent, Uzbekistan.
} 


\title{
Концепция развития системы управления охраной труда в малом предпринимательстве
}

\author{
Ключевые слова: \\ малый бизнес, \\ суот, \\ охрана труда, \\ несчастный случай, \\ круг управления, \\ аудит, \\ ГОСТ, \\ аутсорсинг.
}

\begin{abstract}
АННОТАЦИЯ

В настоящей статье рассматриваются вопросы,
связанные с обеспечением безопасности и охраны труда в
субъектах малого предпринимательства. С помощью
статистического, теоретического и практического анализа
раскрывается сущность системы управления охраной труда
на предприятиях и в частности определяется
неоднозначность её применения для субъектов малого
предпринимательства. В статье приведен сравнительный
анализ системы управления охраной труда в стандартном
её понимании возможности интеграции в неё аутсорсинга.
Исходя из проведенных исследований, предлагается
концепция о необходимости корректировки системы
управления охраной труда. На основе корректирующий
действия предлагается интеграция внешнего управлений
охраной труда для субъектов малого предпринимательства.
\end{abstract}

INTRODUCTION

President Sh.M. Mirziyev at the 75th-quersion of the UN General Assembly paid attention to the fact that these days the tests are given to the population, as well as to the business, including small. Also mentioned by the President, the importance of pandemic, food security directly depends on the small business, [1]. In social plan, small businesses are designed to create a flexible, self-regulating system of uninterrupted community of public consumer goods and various types of services, to promote optimal employment and to more complete the use of personnel potential. It will not be possible to agree that the role of small entrepreneurship in the development of the economy is great. The development of small business is a reflection of overcoming monopolism in the economy, the formation of a cluster of intersectoral industries, as well as small business contributes to the progress of scientific and technical production. In addition to the foregoing, social policy is very important and widely discussed in Uzbekistan. According to the Constitution of the Republic of Uzbekistan, state power is carried out only in the protection of the interests of the people and human rights. Again, in accordance with the Constitution, every citizen has the right to fair working conditions, paid leave, for social security in old age, in the event of a disability, the loss of the breadwinner, [2]. In order to social protection of the population, as well as the protection of the health and life of citizens, a system of labor protection (SYOT) has been operating in the republic, enshrined by the Law of the Republic of Uzbekistan "On Labor Protection". It is worth noting that this system has shown its effectiveness to a greater extent on the businesses of large business and state-owned companies, and the small and medium-sized business sector remained outside the functioning of this system. This is confirmed by the statistics of accidents in the Republic of Uzbekistan by year (Table 1), [3]. 
Table 1.

\section{Number of accidents in the Republic of Uzbekistan by year without the account of small businesses}

\begin{tabular}{|l|c|c|c|c|c|c|c|c|c|}
\hline Year & $\mathbf{2 0 1 0}$ & $\mathbf{2 0 1 1}$ & $\mathbf{2 0 1 2}$ & $\mathbf{2 0 1 3}$ & $\mathbf{2 0 1 4}$ & $\mathbf{2 0 1 5}$ & $\mathbf{2 0 1 6}$ & $\mathbf{2 0 1 7}$ & $\mathbf{2 0 1 8}$ \\
\hline All accidents & 342 & 316 & 318 & 343 & 351 & 269 & 290 & 273 & 268 \\
\hline Industry & 268 & 245 & 262 & 264 & 260 & 201 & 235 & 214 & 207 \\
\hline Construction & 31 & 32 & 18 & 20 & 49 & 33 & 30 & 29 & 28 \\
\hline transportation and storage & 41 & 38 & 33 & 58 & 37 & 27 & 23 & 26 & 29 \\
\hline connection & 2 & 1 & 5 & 1 & 5 & 8 & 2 & 4 & 4 \\
\hline
\end{tabular}

The purpose of this work is to analyze the current system of labor protection (SUD), in particular in small businesses, and determine the directions of its prospective development. To achieve the goal, the following tasks are set: - to analyze the current Syot in the Republic of Uzbekistan; - to reveal the key disadvantages in Syot at small business enterprises; - to determine the vulnerabilities and points of contact with the Soth small in large entrepreneurship; - establish a number of potentially promising directions to improve the Soth in small business. Critical analysis of literature on the topic The issue of labor protection management sounds sharp in the entire post-Soviet space. Amazing is that, in spite of the sufficiently large development of this problem in scientific works, its practical part remains not solved. The problem of ensuring the safety of labor arose in the middle of the 9th century, at the same time, the first standards began to appear such as: regulating working time during the week (no more than 8 hours a day), division of labor of women and children from men, etc. This question in his work was interested in Rumyantseva O.B. Rumyantseva considers the issue of labor safety at small enterprises as one of the dominant factors of economic development of the enterprise, and also determines the factors negatively affecting the worsening of working conditions in Numerous violations by entrepreneurs of small business standards for labor protection are of serious concern. Employers' care from resolving issues in the field of labor protection makes this scope of economics for employees a little attractive in part of providing social guarantees in the field of conditions and labor protection (Rumyantseva O.B.).

Most of the authors who analyzed this issue come to the conclusion that the creation and maintenance of the quality functioning of an SUOT must be carried out in accordance with the cycle (management circle) developed in the 1950s by Deming (Deming Cycle). The cycle includes four stages: planning, implementation, performance monitoring and corrective action development. In the domestic literature, there is an alternative interpretation of the principles underlying the SUOT methodology: "plan - do - control improve", [4].

In the context of OSH management, "Planning" means developing appropriate policies, allocating resources and expertise, structuring the system, identifying hazards, and assessing risks. "Action" is the actual implementation and application of the program. "Control" involves measuring the active and reactive indicators of the program. Finally, "Refinement" completes the cycle by revising the system operation with a focus on continuous improvement and debugging of the SUOT during the next cycle (Sudarkina Kh.V.)

O.V. Chernyshenko in the course of studying the problem of organizing labor protection in small and medium-sized enterprises, he comes to the conclusion that most violations in labor protection legislation in small and medium-sized businesses depend on how the employer treats labor protection issues at his enterprise. 
It is impossible to disagree with the conclusions of the scientific works of the above authors that the leaders of small businesses, as well as large ones, must understand the importance of regulating relations in the field of labor protection, at least they must have the following skills (Pic. 1), given in order of importance:

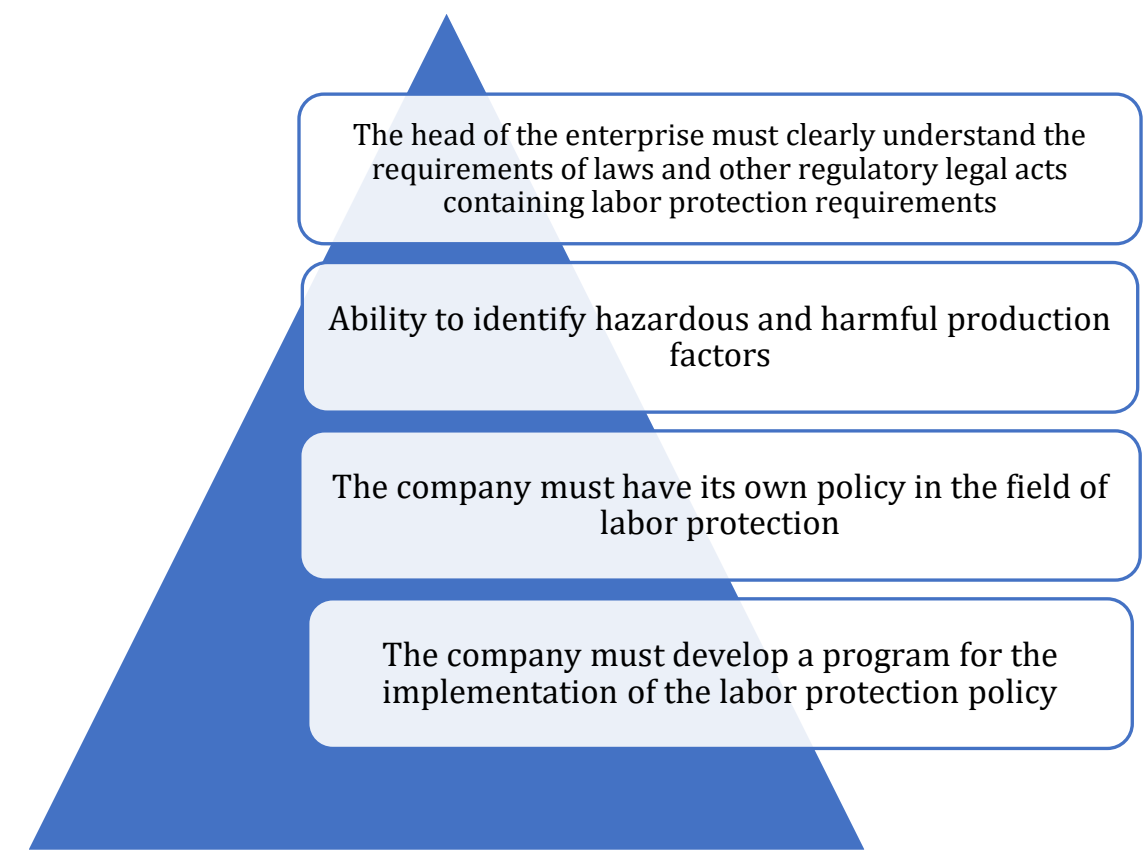

\section{Picture 1. The pyramid of the consequences of creating safe working conditions at the enterprise.}

It is also worth noting that, in fact, no one has proposed a conceptual solution to the problem of labor protection in small business. Along with this, it would not be fair to demand a specific answer from one author. This is due to the global nature of the problem, as well as the variety of technical and functional components of small businesses.

\section{RESEARCH METHODOLOGY}

A set of theoretical and practical analyzes of scientists was taken as the methodological basis of the research to reveal the topic. A comparative analysis, synthesis, systematization and presentation of data from the relevant literature, as well as regulatory and legal acts on the topic of the research were carried out.

Also, the research is based on the author's practical experience in the field of labor protection and the creation of safe working conditions at enterprises, in particular at small businesses.

According to Appendix 1 to the PCM No. 275 of 08.24 .2016 "Classification of organizations related to small businesses", small businesses are divided into sections group-classes - subclasses. The number of employees in micro-firms varies within 20 people, in small enterprises within 270 people. For example: in small enterprises for the production of computers and peripheral equipment, the number of employees can reach 270 (subclass 26.20.0), and in small enterprises specializing in the maintenance and repair of cars, the number of employees should be within 100 people (subclass 45.20.1) [8]. 


\section{Number of small businesses in the Republic of Uzbekistan by region for 2020 (thousand units )}

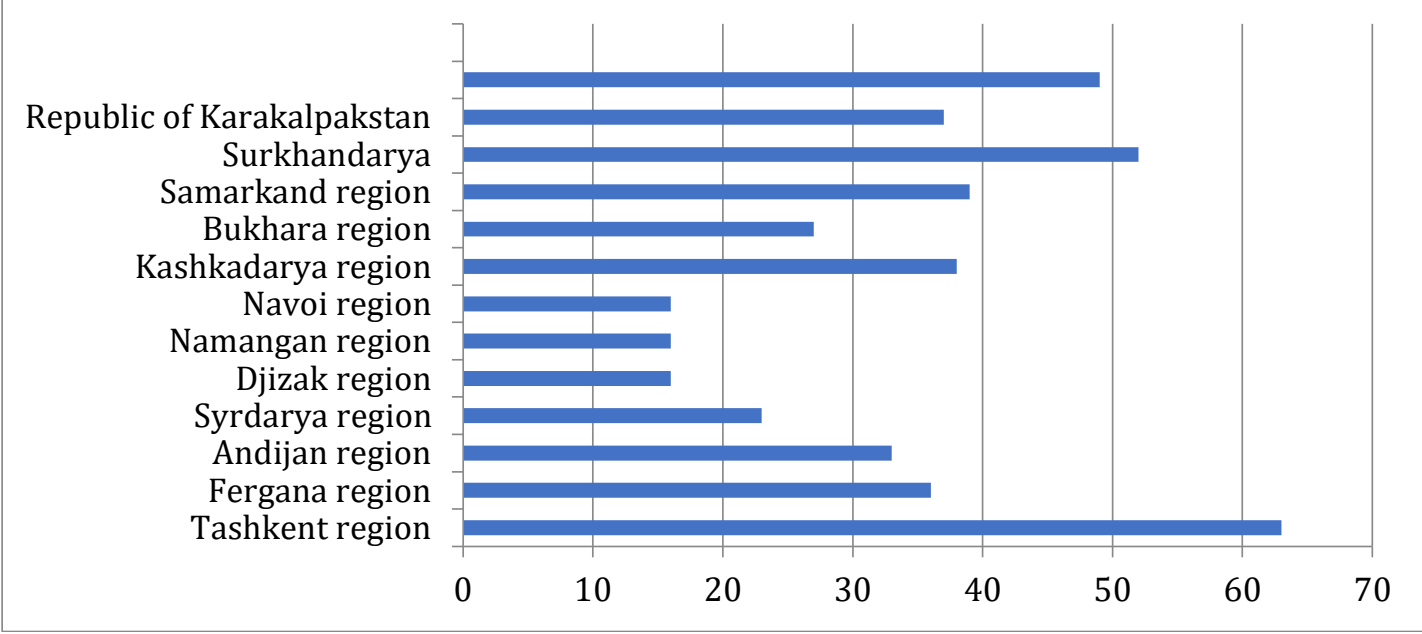

The development of small businesses has a beneficial effect on an increase in employment, but also, unfortunately, it has a negative nature of influence. Working in small business enterprises actual does not have social protection, which is legally enshrined with them in the Constitution of the Republic of Uzbekistan, in the Labor Code and in labor protection legislation. It is on small business enterprises accounting for the greatest number of violations of regulations on labor and labor protection. In the Republic of Uzbekistan, 1.6 times more workers engaged in labor activities in small enterprises than in large industrials. The difficult economic situation of many small business organizations involuntarily pushes into the second plan to improve the working conditions, gives a formal reason to employers not to spend funds to ensure labor protection and the implementation of state regulatory requirements. A large category of small and mediumsized businesses is not engaged in manufacturing activities, respectively, do not fall under the first paragraph of Art. 12 of the Law "On Labor Protection" according to which they do not undertake to include in the staff schedule of labor protection specialist, although they are quite dangerous enterprises. Relationships in the field of labor protection in small businesses remain under the veil of secrets. Analysis and results. The concept of SUOT in its standard understanding, for example, in accordance with GOST 12.0.230-2007 "System of labor safety standards. Labor protection management systems. General requirements" did not show their due efficiency in practice, and especially in small business entities. Also, designed precisely in order to create and regulate SUOT in small enterprises, the standard GOST 12.0.009-2009 "The system of labor protection in small enterprises" adopted as the basic in the Russian Federation is ineffective. This standard has the following main objectives: - formulate the concept of labor protection; - develop and ensure effective functioning, to carry out the continuous improvement of the labor protection management system; - Confirm the compliance of the labor protection management system to this standard by: 1) self-definition of compliance and confirm the compliance of the labor protection management system with the requirements of this standard and informing this as an ad; 2) confirmation of the compliance of the labor protection management system with the requirements of this standard to obtain a certificate of conformity in the third 
party (audit). The basis for creating a labor protection management system in the Republic of Uzbekistan is the Model Regulation No. 273 approved by the Ministry of Labor of July 14, 1996 "On the organization of work on labor protection", which gives the concept that labor protection is a system of interrelated events. Initially, the SUOT model according to the situation is designed for large enterprises and public sector enterprises, which is evidenced by the Third Region Head (Organization of Work on Labor Protection in Ministries, Corporations of Associations, Concern, Production Associations), this can be convinced of this The block diagram of the judiciary of Soth under Regulation No. 273 at small enterprises of any field of activity, even production often absent such positions as: chief engineer, chief mechanic, main energy engineer and the same occupational safety engineer.

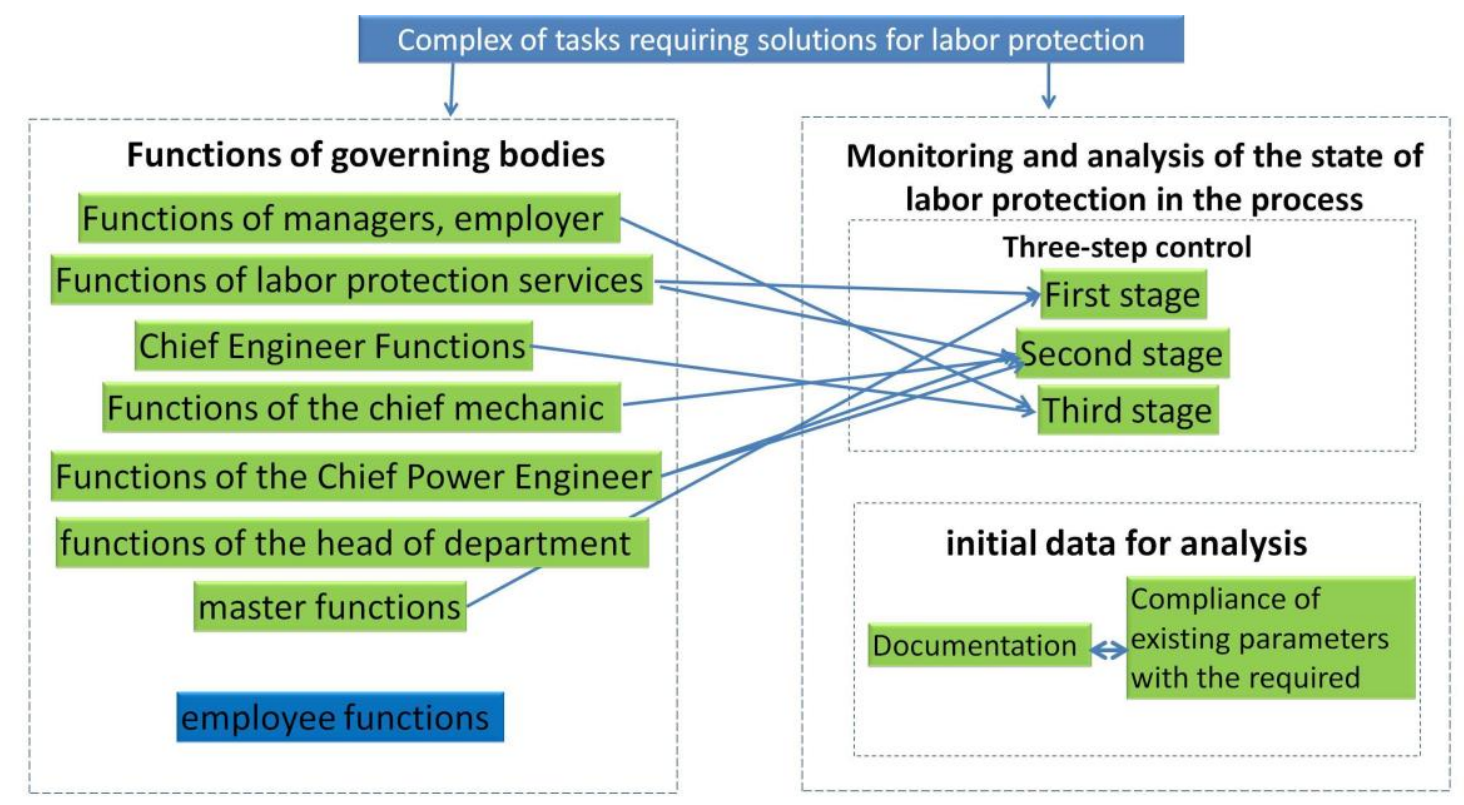

Picture 2. Blockey scheme of the organization of Soth under Regulation No. 273

Most of the responsibilities of the above positions are under the control of the company's head and at the same time mainly all economic functions are delegated to outsource. Accordingly, control over all of the above processes is assigned to the head, including the process of labor protection. If the employees of a small enterprise cannot qualify work on labor protection at the design stage or evaluate the implementation of labor protection requirements at the current enterprise, the interested party should use the services of organizations specializing in solving labor protection issues Of interest is the experience of working on the provision of outsourcing services. This is a way to optimize the activities of the enterprise through the transfer of non-core functions by external specialized companies, Chizhova M.A. [1]

The head of the enterprise is simply not enough to pay attention to all processes, the only reasonable way out in the opinion of the author is the transfer of the labor protection process on an outsource. Moderation of the labor protection management system is key and requiring primary consideration. Before creating a system, the authority should be divided between the head of the organization and the representative of the organization of the provision of outsourcing (outsourcer) Pic.3. 


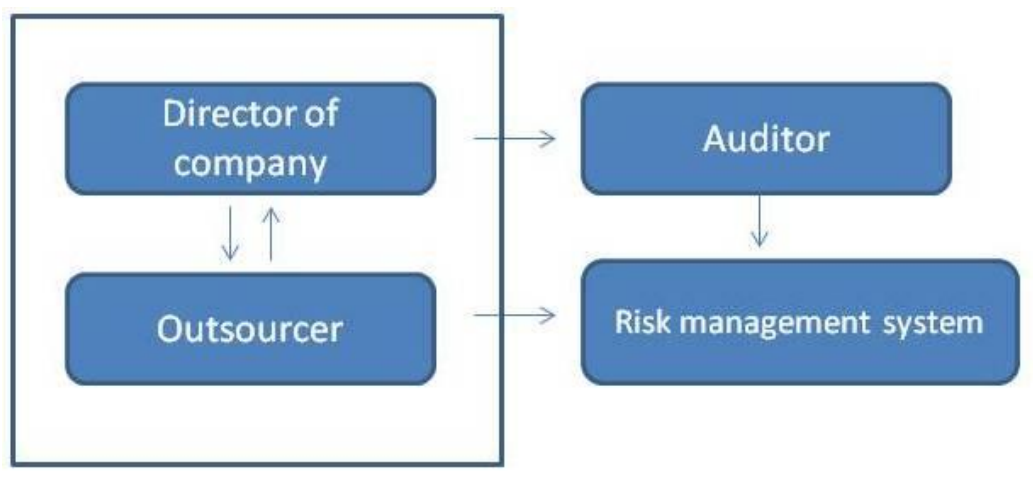

Picture 3. Roles of participants in the system

The roles of participants in the system in this case, the manager must be not a modist of SUOT, but its auditor (controlling body). At the same time, such powers as: financing, distribution of roles within the organization, penalties and some other powers cannot be delegated to outsource. Table 2 presents the distribution of responsibilities for creating a suot in a small enterprise.

\section{Obligations of participants in the system}

Table 2.

\begin{tabular}{|c|c|}
\hline Enterprise manager (employer) & Outsourcer \\
\hline $\begin{array}{l}\text { Preliminary analysis of the state of labor } \\
\text { protection for the current period } \\
\text { (independently, after checking by supervisory } \\
\text { authorities, with the help of an audit) }\end{array}$ & $\begin{array}{l}\text { Analysis of the state of labor protection after } \\
\text { the conclusion of a bilateral contract for the } \\
\text { provision of outsourcing services for labor } \\
\text { protection }\end{array}$ \\
\hline $\begin{array}{l}\text { Coordination and approval of a long-term } \\
\text { plan of mandatory work on labor protection } \\
\text { (development of basic regulatory legal acts on } \\
\text { labor protection, creation of an up-to-date NPD } \\
\text { base, training of persons responsible for labor } \\
\text { protection, etc.) and the timing of its } \\
\text { implementation }\end{array}$ & $\begin{array}{l}\text { Determine and agree on a long-term plan of } \\
\text { mandatory work on labor protection } \\
\text { (development of the main regulatory legal acts on } \\
\text { labor protection, creation of an up-to-date NPD } \\
\text { base, training of persons responsible for labor } \\
\text { protection, etc.) and the timing of its } \\
\text { implementation }\end{array}$ \\
\hline $\begin{array}{l}\text { Coordination and approval of a long-term } \\
\text { plan for additional work on labor protection } \\
\text { (certification of workplaces, preliminary and } \\
\text { periodic medical examination) and the timing of } \\
\text { its implementation }\end{array}$ & $\begin{array}{l}\text { Determination of a long-term plan for } \\
\text { additional work on labor protection (certification } \\
\text { of workplaces, preliminary and periodic medical } \\
\text { examination) and the timing of its implementation }\end{array}$ \\
\hline $\begin{array}{l}\text { f funds for performance of labor } \\
\text { ks }\end{array}$ & $\begin{array}{l}\text { Calculation and coordination of the necessary } \\
\text { funds required to carry out labor protection work }\end{array}$ \\
\hline $\begin{array}{l}\text { Control over the conduct of briefings, } \\
\text { training, tests of knowledge on labor protection }\end{array}$ & $\begin{array}{l}\text { Organization of briefings, training, testing of } \\
\text { knowledge on labor protection }\end{array}$ \\
\hline $\begin{array}{l}\text { Participation in the investigation of accidents } \\
\text { when they occur }\end{array}$ & Investigation of accidents when they occur \\
\hline $\begin{array}{l}\text { Responsiveness and control of labor } \\
\text { protection workflow. Conducting a scheduled } \\
\text { audit of the quality of the service provided by an } \\
\text { OSH outsourcer }\end{array}$ & $\begin{array}{l}\text { Carrying out work to prevent industrial } \\
\text { injuries, occupational diseases (informing about } \\
\text { working conditions, drawing up prescription acts, } \\
\text { proposing penalties for violation of safety rules, } \\
\text { etc.) }\end{array}$ \\
\hline
\end{tabular}


As statistical data show, only $5 \%$ of middle and small enterprises managers are motivated to contact organizations providing services in the field of labor protection. The remaining 95\% do not know about the existence of outsourcing in the field of labor protection, or consider it an excessive burden for business.

\section{CONCLUSION}

The discrimination in the social security of workers of small enterprises is unlikely to be solved by administrative measures. In fact, this aspect of labor relations (and many others in this area) turned out to be completely uncontrollable by state and industry bodies of labor protection, which led to the level of production injuries. Small businesses, "off" from the administrative management system of labor protection, are not subject to market mechanisms that allow to regulate the behavior of the employer in the process of ensuring the legislatively guaranteed safe working conditions of workers. The lack of state administrative and legal regulation of socio-labor relations at small enterprises between employers and employees led to the emergence of a problem situation in the field of labor protection and labor protection. The problem remains open not only in the Republic of Uzbekistan, but also in the CIS countries. The system of labor protection management system developed and implemented at a small enterprise allows to identify production hazards, to assess the risks of death and injury to employees, as well as develop and implement effective measures to reduce them. The main stage of creating a judgment in small enterprises is the need to vaccinate the culture of security to the heads of small enterprises.

\section{REFERENCES:}

1. Speech by the President of Uzbekistan at the 75th session of the UN General Assembly: Full Text // URL: https://uztag.info/ru/news/vystuplenie-prezidentauzbekistana-na-75-sessii-generalnoy-assamblei-oon-polnyy-tekst (23.09.2020).

2. Constitution of the Republic of Uzbekistan// URL: https://lex.uz/docs/35869 (1992).

3. Portal of open data of the Republic of Uzbekistan (accident accident statistics) // URL: https://data.gov.uz/ru/datasets/8574.

4. Rumyantseva O.B. Creating safe working conditions in a small business // thesis on a scientist of the degree, Moscow. - 2006. - PP. 33-39.

5. Interstate Standard of SSBT, GOST 12.0.230-2007 Labor protection management systems. General requirements // URL: https://docs.cntd.ru/document/1200052851.

6. Sudarkin X.B. Laborkeeping management: System, methods and safety of labor protection in the enterprise // International Scientific Journal "Innovative Science" // 2016. - № 6/2016 ISSN 2410-6070. - PP. 155-158.

7. Chernyshenko O.V. Labor protection in small and medium-sized enterprises// Engineering Bulletin Don. - 2016. - № 2. - PP. 99-108.

8. PCM RUz №275 About measures to transition to the international system of classification of economic activities. - Tashkent. - 2016.

9. Typical position approved by the Ministry of Labor RUz №. 273 About the organization of work on labor protection. - Tashkent. - 1996. 